\title{
Abandoned structures: tools for reuse and repurposing of buildings in Slovak municipalities
}

\begin{abstract}
In this article, we aim to analyse the state of abandoned properties in Slovak municipalities and present possible solutions for this issue. In the theoretical part, we define abandonment and the tools for abandonment based on the current literature review. Building on this framework, the paper analyses the towns and villages of selected Slovak region, that being Banska Bystrica self-governing region. To map abandoned properties located in a selected region, as well as to identify emotional value of these building and the instruments needed for their reconstruction or removal, a questionnaire was sent to the mayors of all municipalities of over 1,000 inhabitants in the region of Banská Bystrica - a total of 115 municipalities in 2019. This concentrated research on one region enabled us to have a closer look at the status of abandoned structures in municipalities in a typical area of Central and Eastern Europe. We compare the issue of abandonment in the commuter zone (the two largest cities in the regions and their surrounding) and the hinterlands. Research has shown that the population in the hinterlands is declining more than in the commuter zone, but more abandoned buildings are located in municipalities in the commuter zone. Buildings in need of repair that are important for the inhabitants (e.g. from the point of view of history), are registered in their municipality by $93 \%$ of mayors in the commuter zone and $84 \%$ in the hinterlands. The most frequent obstacles to repairing these buildings are considered by the mayors in both zones the many number of owners who cannot agree on a plan for saving the objects. The quantitative research is completed with an illustration of an abandoned object in Banská Bystrica.
\end{abstract}

KEYWORDS: abandoned properties, public unused properties, public policy, Slovakia

RECEIVED 10 September 2020; ACCEPTED 24 February 2021.

\section{INTRODUCTION}

A vacant and abandoned property is increasingly recognized as a significant barrier to the revitalization of municipalities of various sizes. Burchell and Listokin (1981) describes abandonment as a disease that becomes a feedback mechanism that accelerates and perpetuates community decline. Beauregard (2009) presents an American definition for decline as being deindustrialization, racial tension, suburbanization, poverty, crime, and 'image' cause the periods of loss. For Central Europe, cause for decline can more easily be pinpointed to the change from a command economy to capitalism, which has led to rapid reorganization, de-industrialization followed by suburbanization. This has meant the loss of utility for many older structures. One problem with the study of abandonment, is that it is often framed as an "urban issue" and as such, this adjective excludes consideration of opportunities that lie outside of urban centres. For both small and large communities, abandon structures, especially aesthetically significant structures, are in need of tools to end the status quo of neglect.

The root causes of abandonment are economic and demographic changes that can lead to a vicious cycle of even more abandonment as a life cycle goes (Balco et al., 2018). Obviously, a loss of population would lead to abandonment. Even if an older family member maintains occupancy in a home, the children may have moved on to other localities. When the mother and father dies, the property ownership reverts to the children, but maintenance is not ongoing. Cohen (2001) describes the negative economic and social values created by 'unemployed buildings' that decrease property values, invite vandalism, discourage investments, impose

\footnotetext{
1 Department of Language Communication in Business, Faculty of Economics, Matej Bel University in Banská Bystrica.

2 Department of Quantitative Methods and Information Systems, Faculty of Economics, Matej Bel University in Banská Bystrica.

3 Department of Public Economics and Regional Development, Faculty of Economics, Matej Bel University in Banská Bystrica.
} 
a cost on the municipal government, and generally diminish the quality of life of the local community. Sometimes they can even be a source of crime (Hronec et al., 2014). As such, property ownership cannot be treated as a passive investment if the end result is a derelict building affecting the community. The type of property affects many aspects of community life, including housing and neighbourhood vitality, crime prevention efforts, and commercial district vitality (Accordino \& Johnson, 2016).

The casual observer can easily identify what is an abandoned object - a collapsing roof, broken windows, overgrown plants, litter, and the ubiquitous graffiti are obvious signs of disinvestment and neglect. To aid the topic of this monograph, a definition of abandonment needs to be drafted. The Vacant Property Network of the International City/County Management association defines an abandoned building as being a place where no one resides, and it would be difficult for anyone to occupy without substantial repairs (Schilling, 2002). Instead of focusing on the legal definition of abandonment, this paper will use a generally accepted concept of abandonment - the visual notion of abandonment that is in the mind's eye of most everyone. This definition could also include a mothballed building where an object that has been secured by boarded windows, sealed doors, and/or fencing denying access to the building. Mallach (2006) states that unlike vacant property, an abandoned building is a property whose owner has stopped carrying out a least one of the significant responsibilities of ownership, such as paying property taxes and maintenance.

This paper contends that abandonment is both singular and plural, meaning in that, it can be both an individual object and an entire community. It is not an urban-only conception, yet paradoxically, an old historic object in an urban core is seen as having tremendous economic value because of its nostalgic sentiment, yet the same building loses its utility in a rural setting and is left to rot. Apart from economic opportunity, each community has an emotional value that acts like a magnet with the potential to attract and repulse, especially for the young. This value also extends to abandoned objects, where the emotional value describes both positive and negative responses that the objects elicit. Based on this, the objects can be divided into three categories:

- Positive emotional value - an object that elicits positive emotions. They are enjoyed, yet pitied for being in an abandoned state. There is a strong desire for their renewal and upkeep (examples may include railway properties, older homes, and historic businesses).

- A neutral emotional response - an object that is rather neutral and nondescript. It neither attracts nor detracts from the emotional response to a community.

- Negative emotional values - an object that raises scorn and is seen as a detriment to society. These objects are seen as a reminder of all that is wrong with the town and riddance of their existence would have positive societal impact.

The emotional value can influence the abandonment both ways: a positive emotional response brings a feeling of nostalgia and a desire for a return to a better place. Objects from the past are often looked upon favourably and can be used as an incentive for economic development, i.e. the positive emotional response act as a catalyst to solve the abandonment by saving the building in ways of its reuse or repurposing. On the other hand, an object with a negative response could warrant its removal, i.e. it might speed up the demolishing of an abandoned building. In any case, a set of tools is needed to address the issue.

This was also motivation for conducting this paper, with a main goal to map abandoned buildings located in a selected region, as well as to identify emotional value of these building and the instruments needed for the reconstruction or removal of abandoned buildings. The paper is structured in a following way: after the introduction, the tools to solve the abandonment are presented. The methodology section explains the methods and defines the research questions, which are answered in the results, concluded by discussion and conclusion.

\section{TOOLS TO ADDRESS THE PROBLEM OF ABANDONMENT}

Too often, abandoned buildings are left to fester for years, with no attempts to remediate its condition. The problem is both an issue of money and will for both the municipality and owners of the property. Protection may be allotted for certain buildings in the form of a historic registry, but this does not always allow for rehabilitation of the structure and definitely does not include all buildings that have positive emotional value, e.g. many rail stations in Slovakia are abandoned and do not have historical protection. Whether a building is historical (registered) or abandoned, there is a need to incentivize people to invest resources into the objects that would benefit both the owner and society as a whole. This suggests the need for active intervention rather than bureaucratic indifference. From this perspective and the literary review, we have highlighted some of the tools that could be used to gain interest in these objects according to the level of intervention (Tab. 1). 
Tab. 1: Various solutions addressing abandoned properties

\begin{tabular}{|c|c|c|}
\hline Soft Intervention & Medium Intervention & Aggressive Intervention \\
\hline Planning & Property maintenance & Forced change of ownership \\
\hline $\begin{array}{l}\text { - nationwide strategic plan } \\
\text { - collaboration between public and }\end{array}$ & $\begin{array}{l}\text { - code enforcement } \\
\text { - mothballing }\end{array}$ & $\begin{array}{l}\text { - foreclosure due to lack of tax and penalty } \\
\text { payments }\end{array}$ \\
\hline private entities & Funding & $\begin{array}{l}\text { - property acquisition for redistribution } \\
\text { (land banking) }\end{array}$ \\
\hline $\begin{array}{l}\text { - collaboration between national and local } \\
\text { government. }\end{array}$ & $\begin{array}{l}\text { - creating public/private finance resources } \\
\text { for historic preservation }\end{array}$ & Adaptive reuse \\
\hline $\begin{array}{l}\text { Data collection } \\
\text { - survey of properties }\end{array}$ & $\begin{array}{l}\text { - tax incentives (subsidies, tax breaks) and } \\
\text { disincentives (penalties, higher levies) }\end{array}$ & $\begin{array}{l}\text { - historic preservation } \\
\text { - rezoning }\end{array}$ \\
\hline - abandon property registry & $\begin{array}{l}\text { - homestead rules - tax rules based } \\
\text { on permanent residency/temporary }\end{array}$ & Strategic demolition \\
\hline $\begin{array}{l}\text { - providing information for potential } \\
\text { investors }\end{array}$ & $\begin{array}{l}\text { residency, rental investment, or } \\
\text { "charitable investments }\end{array}$ & $\begin{array}{l}\text { - strategic removal of eyesores and } \\
\text { blighted property }\end{array}$ \\
\hline - heritage database & & Token purchases \\
\hline
\end{tabular}

Based on the literature review (see authors below in text describing the tools in depth) and various solutions found in jurisdictions in the US, UK, and the EU (see Cole et al., 2020).

From the above list, we can further define the terms, specifically in ways that could be adaptable to the CEE region.

Adaptive reuse - The process of reusing an existing building for a purpose other than which it was originally built or designed for. It could be more profound than just changing retailers. It may completely reorient the original intention of a building, for example, converting a deconsecrated church into a home or a factory into a retail space (Bullen \& Love, 2011; Friedman, 2003).

Blighted property - Property that is dilapidated, unsafe, and in unsightly condition. The property presents an imminent danger to other people or property, in terms of both safety and neighbouring property values (Smith, 2014; De Wit, 2008).

Code enforcement - Administration of laws regarding property maintenance and construction. This could include the cutting of grass and trees, repairing of broken windows, maintaining roofs and gutters, removal of trash and debris, removing graffiti, etc. Failure to maintain a property could result in financial penalties for the owner (Greenstein, Sungu-Erylimaz, 2004).

Funding - financial aid from the European Union, mostly Cohesion policies whose support is concentrated more on disadvantaged regions and in traditional sectors with lower added value (Šipikal et al., 2017).

Historic preservation - Managing the physical integrity of nationally designated buildings, sites, objects, and districts as cultural resources and assets for both present and future generations to appreciate and value (Friedman, 2003; Advisory Council on Historic Preservation, 2014; Arrangements for handling heritage applications Direction 2015).

\section{Homestead:4}

Homestead - A dwelling and the land on which it sits, used by a person or a family as their primary residence.

Homestead credit - A tax credit or exemption on property tax to owners who are living in the property or are intending the property to be used as a homestead in the future (i.e. retirement planning).

Historic homesteading - In the past, some countries gave free land to settlers if improvements on the land are made within a specific amount of time. With the achieved improvements, the settler would become owner of the land (e.g. the US, Canada, Australia) (Carter 1967; Shanks, 2005; Moore, 2008).

Land banking - Acquiring, managing, and disposing of vacant, abandoned, and foreclosed property by public or communitybased entities (Frank, 2011; Schilling \& Logan, 2008).

4 This term has multiple definitions and could have different meanings depending on country, tax authority, or municipality. 
Mothballing - Stabilizing securing and protecting a vacant structure from weather damage and vandals while preserving the structure for future use (Community Legal Resources a) and b), n.d.; English Heritage, 2011).

Rezoning - The action or process of assigning land or property to a different category of restrictions on use and development (Ellison \& Burrows, 2007; Kromer \& Kingsley, 2010).

Strategic demolition - The removal of unwanted objects that would result in the enhancement of a community or property. The demolition is carried out in an environmentally friendly fashion (Leonard, Mallach, 2010; Mallach 2006).

Tax based foreclosure - Initiating the repossession of a property due to unpaid taxes and penalties by government entities so that the property can be resold to another person (Perlman, 2012; Remeta et al. 2015).

Token purchases (or modern homesteading) - An initiative created by national and local governments that would discount or give away free property to individuals willing to move to a location, usually a remote or shrinking community, and improve on the property (Kampouris, 2018; Block, 2019).

According to JUDr. Píry (interview, 2020), the state has many laws that make aggressive seizure of property possible, but doing so comes at a cost in legal proceedings that must be borne usually by the local municipality. Normally, the few times this is enforced is when there is an extreme public safety concern such as if a building is at risk to a passing pedestrian (collapse, falling debris) or if the structure is being used for illegal activities (illegal drugs, prostitution). As such, aggressive pursuit of property owners is not a viable solution, especially for small towns.

\section{METHODOLOGY}

In order to determine strategic tools for Slovakia, it was important to reach out to the mayors of the municipalities to analyse the state of abandoned properties in Slovak and present tools for possible solutions for abandonments. It is difficult to separate a community from the objects within the community, as the two are intertwined. A declining population can lead to abandonment, and the general transactional cost to an abandoned object needs to be understood. The aim of this paper is to map abandoned buildings located in a selected region, as well as to identify emotional value of these building and the instruments needed for the reconstruction or removal of these abandoned buildings, i.e. present tools for possible solution of abandonment. These tools may also be appropriate for other countries in a similar situation as Slovakia.

To fulfil the aim of this study, we set up three research questions (RQ):

RQ1: What is the situation with abandoned properties in the Banska Bystrica region?

Based on a questionnaire, we map the main abandoned properties, including their emotional value.

RQ2: What are the possible tools for solving the issues of abandonment?

We map the tools to address the problems of abandoned properties based on the literature review and adapt for the use in CEE region and specifically in Slovakia.

RQ3: What are the drivers that reduce the amount of abandoned properties?

Based on the emotional value, if the building can be reconstructed, what can be done to save the abandoned properties?

RQ4: What are the barriers (obstacles) for "saving" the abandoned properties?

Based on the emotional value, if the building can be reconstructed, what are the obstacles in saving the abandoned properties?

5 JUDr. Martin Píry was appointed bailiff by a decision of the Minister of Justice of the Slovak Republic with effect from 28 February 2012 . He is also a professor at Matej Bel University in the Law Faculty. 
We carried out the research in the Banská Bystrica self-governing region (BBSK), which is the largest region in Slovakia. We focused on municipalities with a population of over 1,000 inhabitants, of which there are 115 in this region out of a total of 516 municipalities. We chose this area because of its size, central location, geographical diversity, and different economic conditions raging from prosperous to poor. Also, this region varies in size from 1,000 to 78,484 inhabitants, i.e. although the sample was not tested for representativeness, it mirrors the situation in many Slovak towns and villages. The sample is divided into commuter zone and hinterlands. The towns of Banská Bystrica and Zvolen form a commuter zone (BB/ZV), with these two towns having a population of around $178,600-27.5 \%$ of the region's population. The rural areas outside of the commuter zone are referred to as the hinterlands.

Focusing only on job opportunities can be misleading because it does not take into account the personal needs of people outside work - e.g. family, community involvement, or creative activities related to home ownership. Therefore, we avoided economic issues and focused more on the objects of the municipality, which give individuals and communities their identity. This also includes the construction of new houses, the revitalization of abandoned property, and the external interest in the community at the level of individuals rather than at the level of society.

Through an electronic questionnaire (containing all types of questions - opened, closed, scale), we contacted 115 mayors at BBSK during the months of January to April 2019, who formed a sample for our research, and we received a total of 51 responses (44.35\% response rate after three rounds of contacting the mayors). The answers were coded in MS Excel and processed in SPSS (Statistical Package for the Social Sciences, version 25).

We first evaluated the obtained results in a summary and then we compared the answers of the mayors according to whether it was inside of the BB/ZV commuter zone or outside of this area, and as such obtained interesting results. We considered all municipalities within the districts (or counties) of $\mathrm{BB} / \mathrm{ZV}$ to be a part of the commuter zone with areas outside of this zone to be hinterland communities.

The quantitative research is completed with a qualitative method of a case study. According to Rubin and Babbie (2001), a case study is an idiographic examination of an individual, family, group, organization, community, or society, and its main purpose is to describe the current status quo and a description of the relationships in their entirety. The case study is a current survey of a current phenomenon. His exploration takes place in his natural environment (Yin, 2009). Other characteristics of the case study method are specific temporal, spatial, and social boundaries (organizations, communities, groups), focus on monitoring phenomena, use of multiple primary and secondary data sources such as document analysis (content analysis), interviews, observation, questionnaires (Swanborn, 2010). To illustrate the problems of abandonment, we selected an abandoned object in Banská Bystrica, namely the House of Culture, as a perfect example of multi-dimensional problems connected to its revitalization. We used personal knowledge of this object and document analysis to describe the issues and barriers of solving the abandonment.

\section{RESULTS}

In this section, we present the main outputs of our research concerning the abandoned buildings, the reason for their abandonment based on the population level in the analyzed municipalities, attractiveness of the municipalities, and tools and barriers for solving the issues of abandonment.

\section{Assessing the data from participating municipalities}

The first question our survey focused on the change in perceived numbers of inhabitants in the municipalities in the last 5 years because a loss of population would lead to abandonment (Cohen, 2001). $51 \%$ of the mayors answered that the population in their municipalities was declining; another $29 \%$ claimed that their number was stable, and only $20 \%$ of them said that there was an increase in the population. There are significant differences between the commuter zone and the hinterlands. The commuter zone reported to have stable (43\%) or increasing (36\%) population, while the hinterlands reported population reductions $(62 \%)$ or stable (24\%), as can be seen in Fig. 1 . 
Fig. 1 Population change in the BB area as perceived by mayors

Population change over the past 5 years

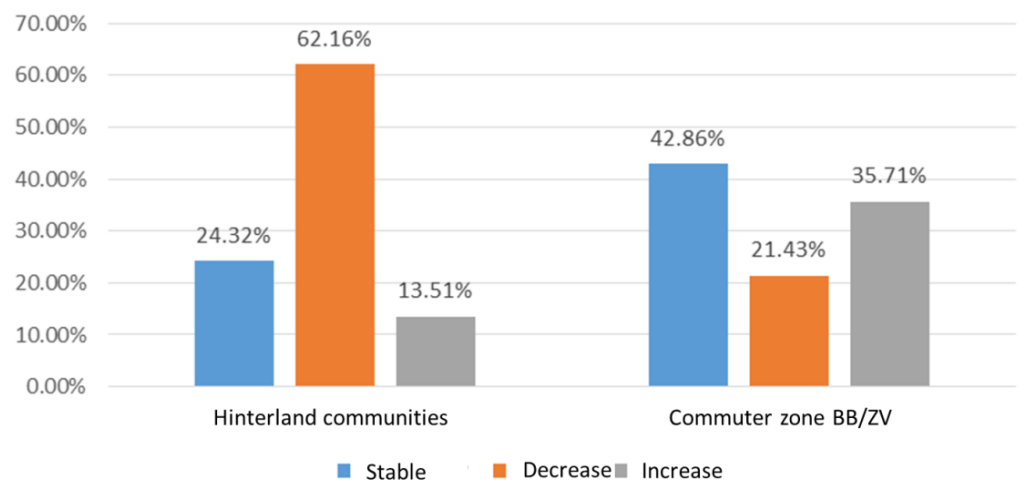

Tab. 2: Ordinal ranking of advantages and disadvantages of municipalities

\begin{tabular}{lll}
\hline Advantages & Rank & Hinterland \\
\cline { 2 - 3 } & BB/ZV & 4 \\
\hline Good location (close to the city, enough jobs) & 1 & 2 \\
\hline Good infrastructure (public transport, roads, Internet) & 2 & 3 \\
\hline Good services (schools, health care, shops, entertainment, etc.) & 3 & 1 \\
\hline Beautiful nature & 4 & 5 \\
\hline Nice architecture & 7 & 6 \\
\hline Possibility to buy real estate as a good price & 5 & 7 \\
\hline Good social and community life & 6 & \\
\hline Disadvantages & Rank & Hinterland \\
\cline { 2 - 3 } & BB/ZV & 1 \\
\hline Few job opportunities, high unemployment in municipalities & 1 & 2 \\
\hline Social Romany problems & 2 & 4 \\
\hline Far from a bigger city & NA & 3 \\
\hline Bad roads & NA & 5 \\
\hline No room for development & NA \\
\hline Lack of infrastructure & NA & 6 \\
\hline
\end{tabular}

Note. Other problems mentioned by the mayors of hinterland municipalities were reluctance to increase population, missing sewers, political party interference.

If we compare our data with the data obtained from the regional statistics of DataCube of the Statistical Office of the Slovak Republic, we can state that for the period 2014-2019, there was a decrease in the population in both zones. The commuter zone had a slight decrease of $0.18 \%$, while outside the commuter zone, the decrease was $1.7 \%$. Overall, if the population of municipalities increased, it was mainly due to suburban municipalities (50\%) or due to the attractiveness of the municipality itself (30\%). Only in the case of $20 \%$ of municipalities, this occurrence was due to the increased birth rate. However, this factor was not proven as a statistically significant in our analysis to influence the level of abandonment. 
Fig. 2: Preferences in the commuter zone

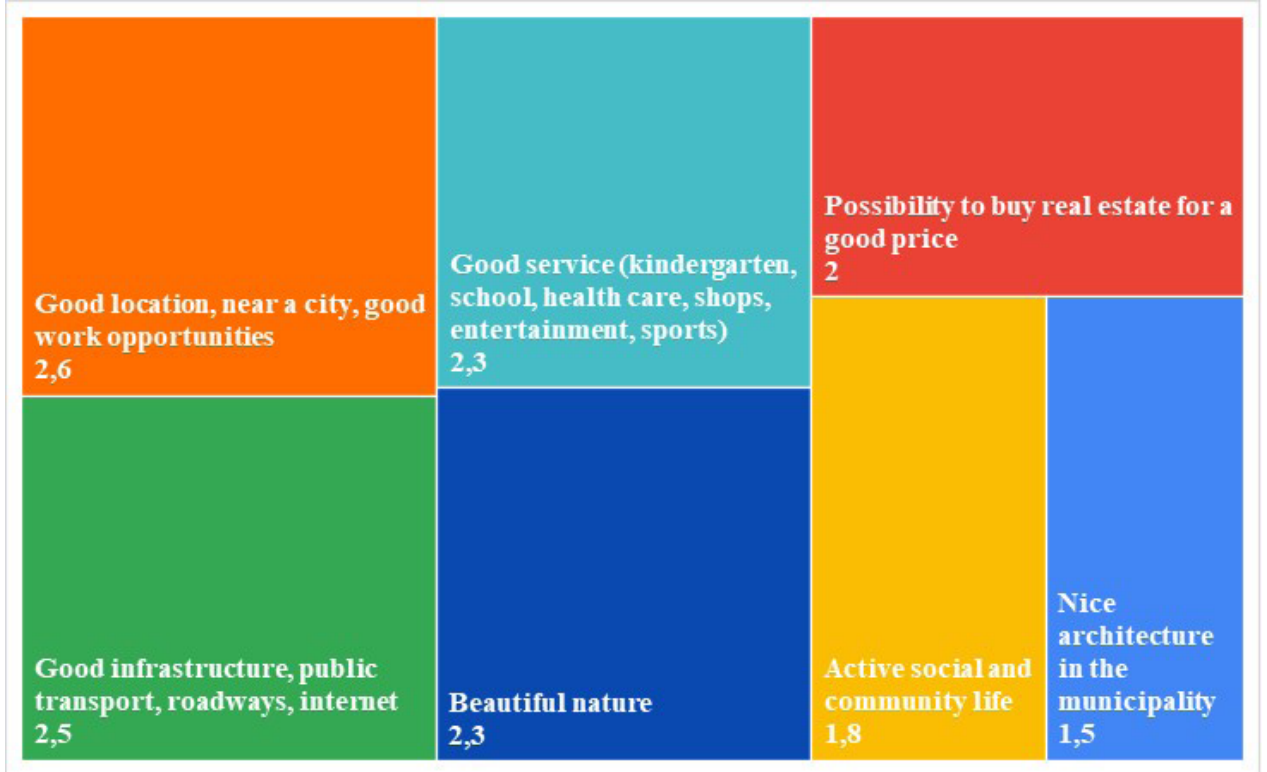

Fig. 3: Preferences in the hinterland

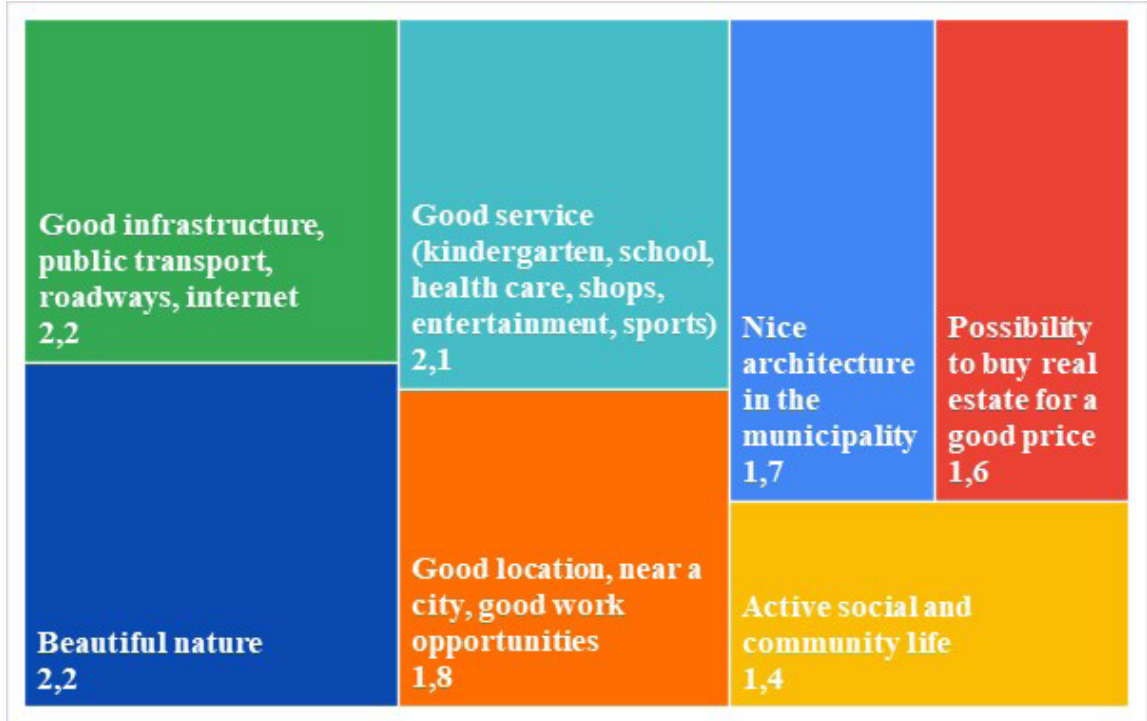

\section{Attractiveness of involved municipalities}

The attractiveness of the municipalities (towns and villages) also influences the abandonment of the buildings, i.e. if a municipality is attractive for living, the buildings are not abandoned or those, which are in the state of abandonment, are sought and bought by newcomers who want to live in the municipality (see Borseková \& Vaňová, 2011, Kitson et al., 2004). The following question asked whether mayors consider their municipalities attractive to new, potential residents. Most of them (up to $82 \%$ ) perceive their community positively in this respect. All of the mayors in the commuter zone felt that their communities were attractive to new residences compared to $76 \%$ of the mayors in the hinterlands, meaning $24 \%$ described their communities as being unattractive to newcomers. 
Fig. 4: The number of abandoned objects in the municipality

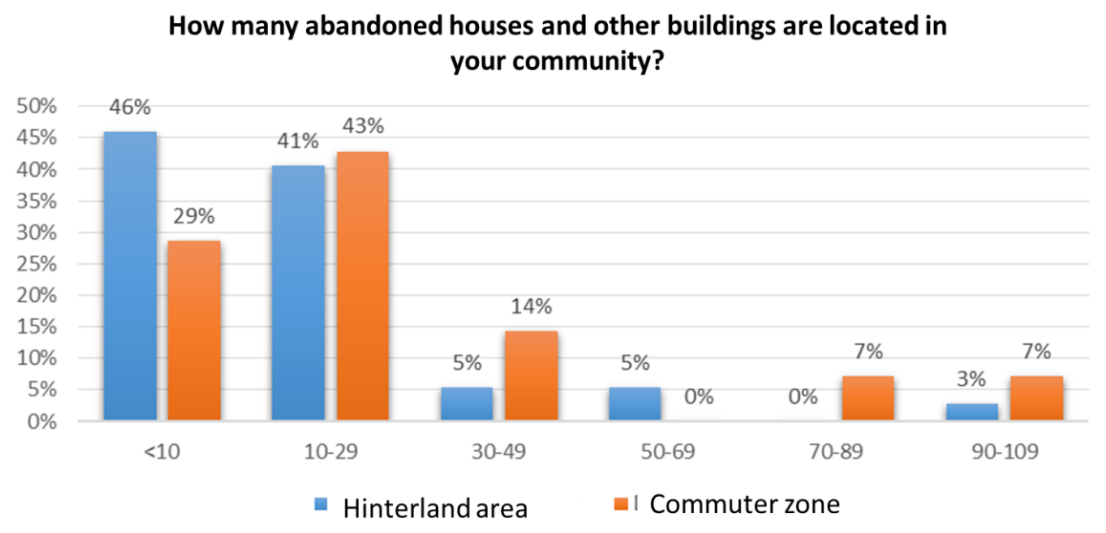

We used a Likert scale to find what aspect the mayors considered most important in determining whether their community is attractive to new residents. We were able to evaluate several indicators, which we proposed as key. Space was provided for mayors to add their own response. The mayors of the monitored municipalities cited beautiful nature, good services (especially kindergartens, schools, and health care), and a good location, close to the city with plenty of job opportunities, as the most common reason for the attractiveness of their village. On this issue, we also observed a significant difference in the views of the mayors of the commuter zone and the hinterlands. A summary of their answers is given in tab. 2.

The mayors of commuter zone mentioned the good location, close to the city with plenty of job opportunities, good infrastructure and good services as the main reasons for their attractiveness. The mayors of the hinterland area cited beautiful nature, good infrastructure, and good services as the main reasons. Both groups agreed that they consider it less important: the possibility of buying real estate at a good price, a lively social and community life, or a nice architectural appearance of the village.

The mayors from commuter zone mentioned the good location, close to the city with plenty of job opportunities, good infrastructure and good services, as the main reason for their attractiveness (Fig. 2). While, the mayors of the hinterlands cited beautiful nature, good infrastructure, and good services as the main reasons (Fig. 3). Both groups agreed that they consider it less important: the possibility of buying real estate at a good price, a lively social and community life, or a nice architectural appearance of the village.

In the following question, we were interested in what the mayors consider to be the biggest barriers in the development of their community. Here, both zones agreed that the biggest barrier is few job opportunities (commuter zone $-47 \%$, hinterland $-41 \%$ ), as well as a high number of socially excluded inhabitants, i.e. the Roma community (commuter zone $-16 \%$, hinterland $-18 \%$ ) and high unemployment (commuter zone $-11 \%$, hinterland $-13 \%$ ). In addition, the hinterland also considers poor access roads to the village (11\%) and too great a distance from larger cities (10\%) to be significant barriers.

Other, albeit less significant, barriers to development in the commuter zone, mayors also mentioned such as the reluctance to increase the population by members of the municipal council, few projects to draw Eurofunds, members of the Smer political party in important positions, lack of individual housing or dangerous conditions in winter. Other less significant barriers to development in the hinterland included lack of space, resulting from the geographical location, lack of building land owned by the municipality, lack of a sewage system, apartments, long distance from the highway, and poor transport links.

\section{Abandoned buildings in participating municipalities}

One of the main goals of our research was to map abandoned buildings located in municipalities, as well as to identify transaction costs for the reconstruction or removal of abandoned buildings so as to make the most of their potential to make the area more attractive to residents and investors. Therefore, the next question addressed the issue of abandoned (uninhabited or unused) houses. The results are presented in the following Fig. 4. 
Fig. 5: New/renovated home construction in the last 5 years

\section{How many new homes have been built or renovated in the last 5 years?}

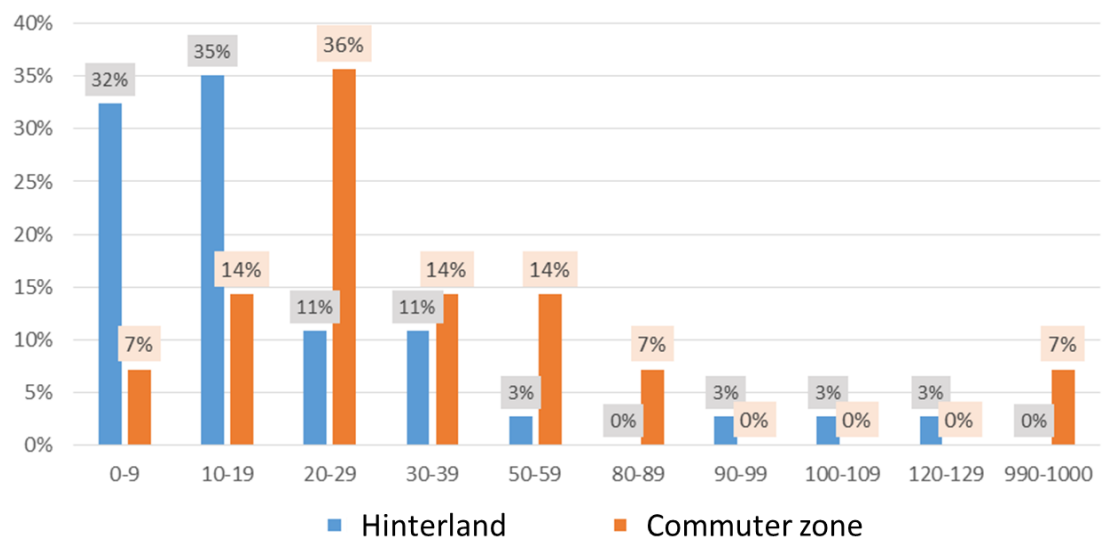

The mayors of both monitored zones agreed that there are either less than 10 such buildings or a maximum of 10-29 buildings (41.2\% each). Other intervals occurred to a much lesser extent, e.g. the number of 30-49 buildings was stated by only a few mayors. It is clear from the graph that 10-29 abandoned buildings most often occur in commuter zone, as stated by almost $43 \%$ of the mayors surveyed. Another $29 \%$ of mayors from commuter zone state that the number of abandoned buildings in their municipality is lower than 10 , and $14 \%$ of them admit that their number of abandoned buildings is in the range of up to 30-49. As far as the hinterland is concerned, as many as $46 \%$ of mayors state that the number of their abandoned buildings is less than 10 , and another almost $41 \%$ of mayors admit that their number ranges from 10 to 29. To this question, we found how many abandoned houses and other buildings are directly owned by the municipality; surprisingly, up to $51 \%$ of all mayors answered none. Only one abandoned building is reported by $19.6 \%$, and another $17.6 \%$ is reported to have two such buildings. The overview is in Fig. 5.

As many as $36 \%$ of the mayors from the commuter zone claim that 20-29 new houses have been built in their municipality, and another $14 \%$ agree that it was in the range of 10-19, 30-39, or 50-59. The most common interval given by mayors from the hinterland (35\%) was 10-19. This was followed by an interval of $0-9$, which was mentioned by up to $32 \%$ of mayors, and an interval of 30-39 by another $11 \%$ of mayors. We can conclude that more individual houses are being built in the commuter zone, which is not surprising.

To an open-ended question: "If it were possible to sell an unused municipal building, would you be reluctant to do so? If so, why?", the mayors of commuter zone and the hinterland mostly reacted negatively. They stated that they would rather look for new uses for such a building and the property of towns and villages should be expanded and developed, not sold out. Some said they would like to renovate and rent such a building. If they decide to sell an unused building, then it should only be at the market price and depending on the specific building.

To the question: "Are there people in your village who are interested in abandoned properties and their repair?" We also received various answers from the mayors of commuter zone and hinterland (Fig. 6).

While in the commuter zone, the three top responses are 1) people without permanent residence in the village are interested in such objects - without family and relationship ties to the village; 2) followed by inhabitants without permanent residence in the village - relatives, heirs, etc.; and 3) the inhabitants of the village themselves. The situation is different in the hinterlands. Here, 1) the residents of the village themselves are especially interested in abandoned buildings, followed by 2) residents without permanent residence in the village - without family and relationship ties to the village, and 3) legal persons - entrepreneurs followed. As many as $15 \%$ of the mayors from the hinterlands stated that there is no interest in abandoned buildings in their municipality, while in the commuter zone, only $6 \%$ of the mayors stated this possibility. As for the interest of entrepreneurs, the results showed that their share is approximately the same in both areas at the level of $16 \%$. Non-profit organizations are also partly interested in abandoned buildings in commuter zones $(6 \%)$, while in the hinterland, their interest is zero. 
Fig. 6: Interest in abandoned property in the community

\section{Are there people interest in the abandoned properties in your community and their eventual repair}
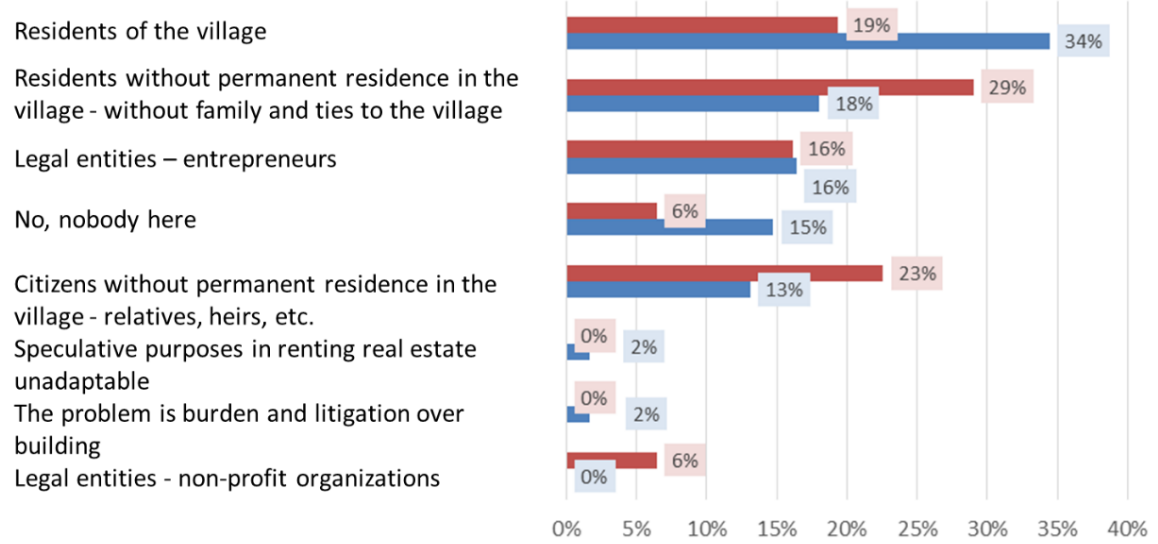

- Commuter zone Hinterland

Fig. 7: Problems with acquiring property

\section{If someone was interested in buying an abandoned property, what were the most common problems with acquiring it?}

Owners did not want to sell the property, even if they no longer maintained it

Too many owners or unknown owners

Wanted higher price than is acceptable on the market

Property was inherited and new owners want to keep this property for a weekend home.

Banks have a lien on the property

There are no problems, owners try to sell quickly

Very complicated paperwork

Neighbours made problems when someone wanted to buy and renovate

Owners refuse to sell property when investors want to make a bigger parcel of land for industry or flats.

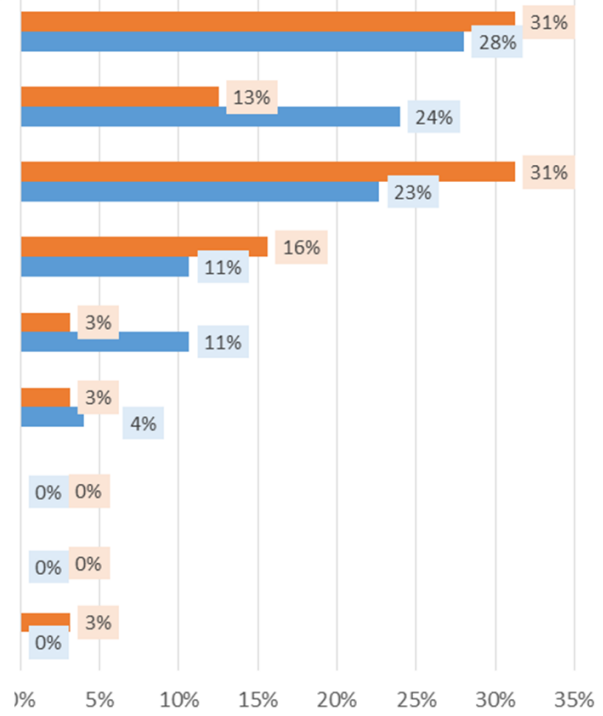

Commuter zone Hinterland

If someone was interested in buying an abandoned property (e.g. a house or building), the most common problems with acquiring ownership in the commuter zone were: 1 ) owners did not want to sell the property, even if they no longer maintained it $(31 \%) ; 2)$ asking too much for it and they wanted a higher price than is acceptable on the market (31\%); 3) the abandoned property was inherited and the new owners kept it with the vision that they would turn the building into a "weekend house" (16\%). The mayors in hinterland also stated as the most common problems were: 1) the owners did not want to sell the property even though they no longer maintained it $(28 \%), 2)$ a large number of owners or unknown owners $(24 \%)$, and 3$)$ the fact that the owners wanted 
Fig. 8: Assistance to potential owners

\section{Does your municipality provide any form of assistance beyond the statutory obligations for those who buy an abandoned building in the municipality for the purpose of its evaluation?}

\author{
Help with documentation and paperwork \\ Help with waste removal \\ There is no form of help \\ Can help owners with certain piece of \\ construction machinery
}

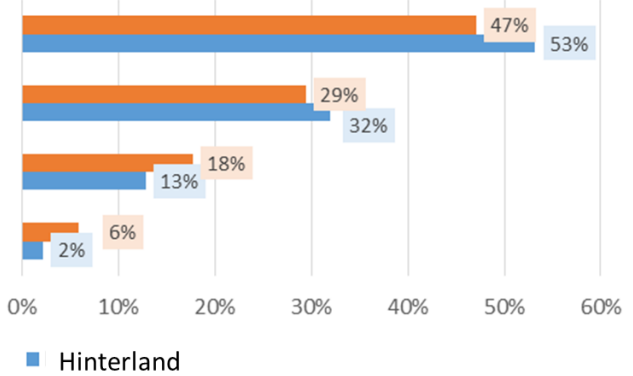

- Commuter zone Hinterland

too high a price for the property $(23 \%)$. Only $4 \%$ of the mayors in hinterland and $3 \%$ in the commuter zone stated that there were no problems with the sale of the property, and the owners tried to sell the abandoned building as quickly as possible, at any price (Fig. 7). No mayor from either area complained about the complicated processing of documentation, or that the neighbours in the surrounding houses were having problems if someone wanted to buy and renovate an abandoned building near them. Also, owners refusing to sell the property, when it was clear that the investor was trying to create a larger plot for industrial, commercial, or residential construction, was mentioned by only 3\% of the mayors of the commuter zone and by none of the mayors in the hinterlands. We can, therefore, conclude that the most common source of problems in this area was the owners or heirs of real estate themselves, approximately to the same extent in both areas.

When asked whether the local government provided some form of assistance beyond the statutory obligations for those who buy an abandoned building in the municipality, the mayors of both areas answered in the same way. They most often mentioned helping with documents and permits $-47 \%$ for the commuter zone and $53 \%$ for the hinterlands. There was some aid for waste removal and disposal that was reported by $29 \%$ of the commuter zone and $32 \%$ of the hinterlands. $18 \%$ of municipalities from the commuter zone and $32 \%$ from the hinterland do not provide any form of assistance. Only a small number of municipalities (6\% commuter and $2 \%$ hinterland) could lend owners essential equipment - e.g. excavator or a truck for a fee (Fig. 8).

Buildings that have a positive relationship with local inhabitants, but are in need of repair are reported by $93 \%$ of the mayors in the commuter zone and $84 \%$ of the mayors in the hinterlands. The most frequent obstacles to repairs of these buildings in the commuter zone are reported to be the large number of owners who cannot agree (33\%); there is no problem for reconstruction and there is an ongoing plan (27\%); the building is privately owned, but the owner does not have the funds to repair it; the building is owned by the municipality, but there is no funds to repair it (20\%). As far as the hinterlands is concerned, mayors also cited as the most common obstacle being the large number of owners who cannot agree (50\%); followed by the building being privately owned, but the owner does not have the funds to repair it (25\%); the building is owned by the municipality, but it does not have the funds to repair it (18\%). Only $7 \%$ of the mayors stated that there are no obstacles and the reconstruction of the building is planned, in contrast to the commuter zone, where it was up to $27 \%$.

In addition to the steps taken by the mayors in the commuter zone, the mayors from the hinterlands also stated that they are trying to sell the buildings based on a public tender or rent them out. Others state that they are trying to renovate them from their own resources or are waiting for appropriate proposals so that they can reconstruct them from European Union (EU) funds.

\section{The House of Culture - no vision for the future}

To illustrate the issue of abandonment, we briefly present a selected case study, The House of Culture (more case studies can be found in Murray Svidroňová et al., 2020 or Cole, et al., 2020). The House of Culture opened in 1979, on Námestie slobody (Freedom square) in Banská Bystrica, which is one of the newest squares in the city, built during socialism, and according to communist plans, 
Fig. 9: Obstacles to preventing repairs of buildings with a positive influence on the local inhabitants

\section{If so, what obstacles are preventing repairs?}

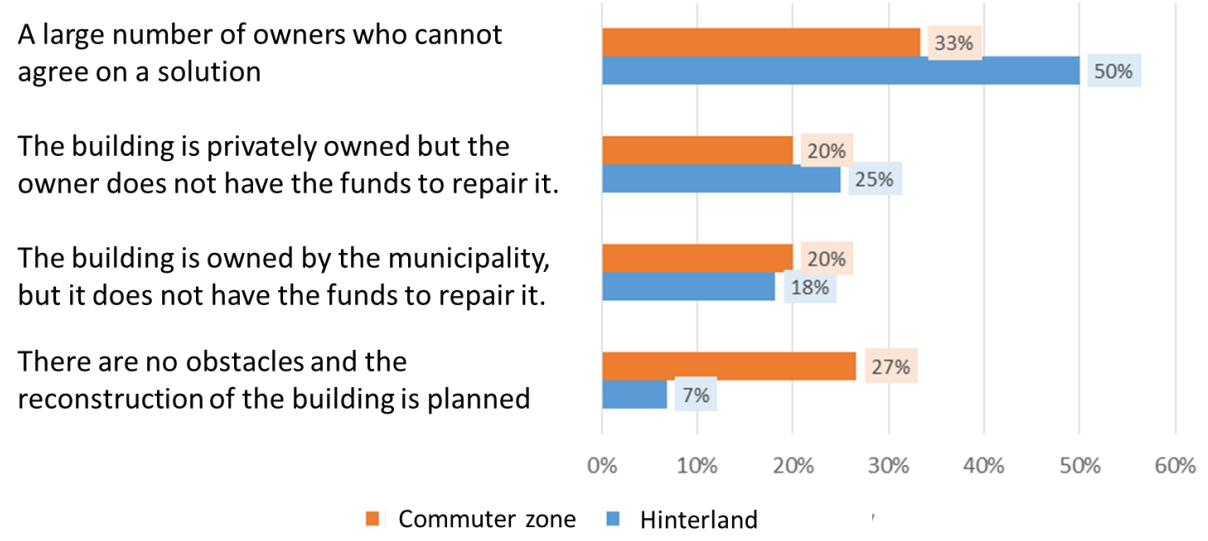

the square was to become the new city centre. In the same year, the building won the Award of the Association of Slovak Architects and was proposed to be registered as a national cultural monument: high glass walls, chrome railings, pleasant colours of ceramic tiles, there was no skimping on the quality of materials. At the time of its greatest glory, various cultural and social events took place here regularly - theatre performances, concerts, films, and balls. The architect managed to achieve admirable variability and flexibility of the interior with the intentions of late functionalism. Later, the building was used mostly as a cinema (OA HÚ SAV, 2020).

But, after 2005, the fate of this and other cinemas in Slovakia have been sealed by modern multiplexes that offer efficient cinema operations. Today, the only functional cinema, Europa Cinemas multiplex, suffices to accommodate Banská Bystrica and its surroundings, and the House of Culture was abandoned. The city of Banská Bystrica expressed interest in buying this building, in 2007, but its original owner, the Trade Union KOVO, received a better offer from the development company VAV Invest, s.r.o. This private company presented an ambitious plan to restore the House of Culture, but eventually it went bankrupt. The city of Banská Bystrica has expressed interest in purchasing this building several times, but was discouraged by the high price demanded by the seller. Since 2017, this building has been on offer with its price being presented to interested parties upon request. Even after many years, the future of the House of Culture remains uncertain and without a vision for future use. With the current financial crisis caused by the coronavirus pandemic, the problem of this object may be extended for years to come. (Cervenansky, 2020).

\section{CONCLUDING REMARKS}

Research has shown that the number of inhabitants in the municipalities of the hinterland is decreasing more than in the commuter zone, which was also confirmed by data obtained from the Statistical Office. But, this fact has not influenced the abandonment in the researched municipalities, which is in line with McLeman (2011) who states that municipality abandonment is a possible result of population decline but is not inevitable. One of the main goals of our research was to map abandoned buildings, as well as to identify emotional value of these building and the instruments needed for their reconstruction or removal. The emotional value of a place or building brings a nostalgic sentiment, which is a main concept of so-called nostalgianomics. Nostalgianomics explains that nostalgic sentiment can be used as an economic and creative force, as an incentive for investment, housing and urban planning (Krugman, 2017; Murray Svidroňová et al., 2019). Buildings that are important for the inhabitants and have a positive relationship with them (e.g. from the point of view of history) and require repairs, are registered in their municipality by up to $93 \%$ of mayors in the commuter zone and $84 \%$ in the hinterlands. Nostalgic sentiment can incentivize people to invest resources into the objects that would benefit both the owner and society as a whole. This is mostly happening due to activities of non-governmental organizations who find the ways of repurposing the unused buildings, e.g. an old bastion for a literary café or return the property its original 
use (Cole et al., 2020; Horvat, 2020); and also activities of communities and informal initiatives (Borseková et al, 2016, Murray Svidroňová, 2021).

The first research question on mapping the abandoned properties located in a Banská Bystrica region is mostly answered in the figure 4, where the mayors of both monitored zones agreed that there are either less than 10 abandoned buildings or a maximum of 10-29 buildings.

Another goal mapping the abandoned buildings located in municipalities was to make the most of their potential to make the area more attractive to residents and investors. Research has shown that the commuter zone residents especially prefer a good location (close to the city with plenty of job opportunities), while hinterland residents preferred beautiful nature and good infrastructure (public transport, roads, internet). These are perceived as drivers for lowering the amount of abandoned buildings, which answers the second research question (What are the drivers that reduce the amount of abandoned buildings?).

Both groups of mayors most often claim that none of the abandoned buildings belongs to the ownership of the municipality - commuter zone (36\%) and hinterland (57\%). In both zones, there are residents who are interested in abandoned properties and their repair. While in the commuter zone, most residents without permanent residence in the municipality are interested in such objects (without family and relationship ties to the municipality), in the hinterland it is especially the inhabitants of the municipality themselves who are interested in abandoned objects.

To answer the RQ3 (What are the barriers for "saving" the abandoned building?), we present the summarized results as follows: if someone was interested in buying an abandoned property (e.g. a house or a building), the most common problems with acquiring its ownership in both zones were that the owners did not want to sell the property even though they no longer maintained it $-31 \%$ in the commuter zone and $28 \%$ in the hinterland. The most frequent obstacles to repairing the abandoned buildings are considered by the mayors in both zones to be a large number of owners who cannot agree with a plan for saving the building - 33\% in the commuter zone and $50 \%$ in the hinterland. To the open question: "If the building is owned by the municipality, what steps did the municipality take to save the building?", the mayors in the commuter zone most often answered in the sense that they try to use all available forms, especially state aid and various funds. In addition to the steps taken by the mayors in the commuter zone, the mayors of the hinterland also stated that they are trying to sell the buildings based on a public tender or to lease them.

The instruments/tools are listed in the separate section, by presenting them we answer the RQ4 (What are the possible tools for solving the issues of abandonment?) and we also list the most suitable tools for the Banská Bystrica region based on the analysis:

1. To provide clarity to the responsibility of ownership of property in terms of maintenance and their civic duty to the community, whether they live in the community or not.

2. To provide a simple way to find an easy to use database of historically/aesthetically interesting property that is defined by the local inhabitants (as well as an official board). This database should be open for suggested nomination of buildings to the registry. There should also be a database of less desirable abandoned buildings so that there could be a determination of their future usefulness or possible removal.

3. The reduction in transaction cost to both absentee current owners and to new potential investors.

The most suitable tools seem to be: adaptive reuse of the property as this is already happening, e.g. in Zvolen (repurposing of the old grammar school) and Banská Bystrica (community centre in an old primary school, etc.) and token sale of a property to investors, essentially giving away property for $1 €$ with certain conditions. For BBSK, this has occurred with high-profile properties such as castles and manor houses (e.g. Viglaš, Halič).

The EU zone as a whole has a cultural panache that is unavailable anywhere else in the world. Metaphorically, Europe is the "Disneyland" of continents and even more so with the adoption of the EU. As individuals, being a part of the European Collective can be considered a coveted prize. The preservation of this culture, through property purchase and renovation could provide buyin opportunity for both Europeans and non-Europeans alike. This might even afford individuals the status of residency within the region, i.e. the creation of a new class of immigrants, based on the preservation of a cultural past.

During the conducting of this research, the defining event of 2020 (the COVID-19 pandemic) has given renewed interest to small town settings, as the ability to work remotely is no longer just a theoretical possibility. This could give new life to disused buildings in both small cities and even smaller towns and villages. What is needed is a set of tools that address the issue of long-term abandoned properties. 
Asking only the mayors of the municipalities is a limit to this research - their answers might have been subjective; however, mayors as elected representatives have the best overview on the issues in the municipality; in case of bigger municipalities, the survey was filled in in the cooperation with the department of construction or respective departments that could provide facts for the questionnaire. The future research should include also the view of citizens and other important stakeholders (Mikušová Meričková \& Jakuš Muthová, 2019), e.g. non-governmental organization who often take an initiative to save an abandoned building. Also, the future research will focus on the emotional value of abandonment and will be used as analytical framework for further analysis.

\section{ACKNOWLEDGMENTS}

This work was supported by the VEGA Agency under Grant [number V-18-101-07-101312].

\section{REFERENCES}

Accordino, J., \& Johnson G. (2000) Addressing the Vacant and Abandoned Property Problem. Journal of Urban Affairs, 22(3), 301-315.

Advisory Council on Historic Preservation (2014). Rightsizing Task Force, Managing Change: Preservation and Rightsizing in America.

Balco, M. et al. (2018). Application of the lifecycle theory in Slovak pension system. Ekonomický časopis, 66(1): 66-8o.

Block W.E. (2019) Homesteading City Streets: An Exercise in Managerial Theory. Property Rights. Palgrave Studies in Classical Liberalism. Palgrave Macmillan, Cham. Retrieved from https://doi.org/10.1007/9783-030-28353-7_20.

Borseková, K., Vaňová, A. (2011) Competitive Advantage of Slovak Republic, International Journal of Multidisciplinary Thought 1(4), pp. 237-257.

Borseková, K., Vaňová, A., Vitálišová, K. (2016). The Power of Communities in Smart Urban Development. Procedia-Social and Behavioral Sciences, 223, pp. 51-57.

Bullen, P., Love, P. (2011). A new future for the past: a model for adaptive reuse decision-making. Built Environment Project and Asset Management. 1 (1): 32-44. doi: 10.1108/20441241111143768.

Carter, I. (1967). Homesteading in Australia. Green Revolution, 5(7), 20.

Cervenansky, S. (2020). Budúcnost’ Domu kultúry ostáva nejasná, aj po tret’om kole dražby chýba záujemca. Retrieved from https://bbonline. sk/foto-buducnost-domu-kultury-ostava-nejasna-aj-po-tretom-koledrazby-chyba-zaujemca/

Cohen, J. (2001). Abandoned Housing: Exploring Lessons from Baltimore. Housing Policy Debate 12, no. 3 January 2001, pp. 415-416

Cole D.A, Murray Svidroňová M., Gubalová J., Kožiak R. 2020. Opustené budovy v kontexte rozvoja samospráv na Slovensku. Banská Bystrica : Belianum. Vydavatel'stvo Univerzity Mateja Bela v Banskej Bystrici, 2020.
Community Legal Resources, a), n.d. "Vacant Properties Toolbox: Complete Guidebook". Detroit Vacant Property Campaign.

Community Legal Resources, b), n.d. "Vacant Property Legal Manual". Michigan State Housing Development Authority.

De Wit, J. (2008). Revitalizing blighted communities with land banks. Retrieved from http://umich.edu/ econdev/landbank/

Ellison, N., \& Burrows, R. (2007). New spaces of (dis) engagement? Social politics, urban technologies and the rezoning of the city. Housing Studies, 22(3), 295-312.

English Heritage (2011). Vacant Historic Buildings: An Owner's Guide to Temporary Uses, Maintenance and Mothballing.

Frank, A. (2011). Land Banks and Land Banking. Center for Community Progress, ISBN 0615471765, 9780615471761.

Friedman, R., (2003). Vacant Properties in Baltimore: Strategies for Reuse (Submission for the Abell Foundation Award in Urban Policy).

Gov.uk (2015). Arrangements for handling heritage applications Direction 2015. Retrieved from https://www.gov.uk/government/publications/ arrangements-for-handling-heritage-applications-direction-2015

Greenstein R., Sungu-Erylimaz, Y. (2004). Recycling the City: The Use and Reuse of Urban Land. Cambridge: Lincoln Institute of Land Policy.

Horvat, T. (Ed.). (2020). Selected Aspects of Non-Profit Organisations. IntechOpen. DOI: 10.5772/intechopen.89482.

Hronec, Š., Mikušová Meričková, B., Štrangfeldová, J. (2014). Social noneconomic effects of education on the level of crime. The New educational review, 38(4): 43-56.

Interview with JUDr. Martin Píry on legislation concerning the abandoned properties. Conduced in May 2020. 
Kampouris, N., (2018), Ready to Go? Greek Island Will Pay You to Live There, Greek reporter. Retrieved from https://greece.greekreporter. com/2018/12/21/ready-to-go-greek-island-will-pay-you-to-live-there/

Kitson, M., Martin, R., Tyler, P. (2004). Regional Competitiveness: An Elusive yet Key Concept? Regional Studies, 38(9), pp. 991 - 999.

Kromer J., Kingsley C. (2010). Vacant Property Reclamation through Strategic Investment in Eastern North Philadelphia, 1998-2010. University of Pennsylvania, Fels Institute of Government.

Krugman, P. (2017). The Gambler's Ruin of Small Cities, The New York Times, Dec. 30, 2017. Retrieved from https://www.nytimes. com/2017/12/30/opinion/the-gamblers-ruin-of-small-cities-wonkish. html

Leonard J., Mallach, A. (2012). Restoring Properties, Rebuilding Communities: Transforming Vacant Properties in Today's America. Center for Community Progress.

Mallach A. (2006). Bringing Buildings Back: From Abandoned Properties to Community Assets. 2nd ed. Montclair, NJ: National Housing Institute.

McLeman, R. A. (2011). Settlement abandonment in the context of global environmental change. Global Environmental Change, 21, S108-S120.

Mikušová Meričková, B., Jakuš Muthová, N. (2019). Bounded Rationality of Individual Action in the Consumption of Public Goods. NISPAcee Journal of Public Administration and Policy, 12(2), 157-194.

Moore, J. W. (2008). Property tax equity implications of assessment capping and homestead exemptions for owner-occupied single-family housing. Journal of Property Tax Assessment \& Administration, 5(3), 37-72.

Murray Svidroňová, M. (2021). Role of civil society organizations in repurposing of unused property. A chapter accepted for Lex localis Open Access Book Series.

Murray Svidroňová, M., Cole, D., Gubalová, J. (2019). The Nostalgianomics and Living Preference in Slovakia. Lex Localis-Journal of Local Self-Government, 17(3), pp. 873 - 895.

Murray Svidroňová, M., Vaceková, G., Kubišová, L. 2020. The role of social innovations in building the nonprofit sustainability: new approaches to marketing. In Kresa, Z. (ed.) Opportunities and Threats to Current Management of Non-profit Organization in Cross-border Comparison. Chemnitz-Lossnitz: Verlag der GUC.

OA HÚ SAV (Register modernej architektúry). (2020). Dom kultúry v Banskej Bystrici. Retrieved from https://www.register-architektury.sk/ objekt/3o8-dom-kultury-v-banskej-bystrici

Perlman, M. (2012). Municipal Action Guide: Managing Foreclosures and Vacant Properties Washington, D.C. National League of Cities.
Remeta, J., Perret, S., Jareš, M., Brys, B. (2015). Moving Beyond the Flat Tax - Tax Policy Reform in the Slovak Republic. OECD Taxation Working Papers, No. 22, OECD. Retrieved from http://dx.doi. org/10.1787/5js4rtzr3ws2-en

Rubin, A., Babbie, E., 2001. Research methods for social work. Belmont: Wadsworth / Thomson Learning.

Schilling, J. (2002). The Revitalization of Vacant Properties: Where Broken Windows Meet Smart Growth. International City/County Management Association. Retrieved from https://citeseerx.ist.psu.edu/viewdoc/ download?doi=10.1.1.188.9674\&rep=rep1\&type=pdf

Schilling, R., Logan, J. (2008). Greening the Rust Belt. Journal American Planning Association 74, no. 4: 451-466.

Shanks, T. R. (2005). The Homestead Act: A major asset-building policy in American history. Inclusion in the American dream: Assets, poverty, and public policy, 20-41.

Smith, M. (2014). No Property Left Behind: An Exploration of Abandoned Property Policies. (Master's Thesis, University of Pennsylvania, Philadelphia, PA). Retrieved from https://repository.upenn.edu/hp_ theses/554/

Statistical Office SR (2020). DATAcube Demographic and social statistics. Retrieved from http://datacube.statistics.sk/\#!/lang/en

Swanborn, P. G., 2010. Case Study Research: What, Why and How? London: SAGE.

Šipikal, M., Szitásiová, V., Pisár, P., Uramová, M. (2017). Spatially blind or place based policy? A comparison of innovation support in the Czech and Slovak Republic. E+M: Ekonomie a Management, 20(1), pp. 16-27.

Yin, R. K., 2009. Case Study Research. Design and Methods. London: Sage Publications. 